\title{
Doppler assessment of uterine and intraovarian blood flow in patients with genital endometriosis
}

\author{
V. D. Vorobii
}

State Higher Educational Establishment “Ivano-Frankivsk National Medical University”, Ukraine

The spread of endometriosis among women of reproductive age is 5-10\%. Forming of endometrioid foci commonly begins from development of new blood vessels. So, changes of hemodynamics in vessels that can be determined by Doppler are important for complete diagnosis of endometriosis.

Aim of research was to evaluate the uterine and intraovarian hemodynamic changes in women with internal and external genital endometriosis.

Materials and methods. The research included 65 women with diagnosis of external genital endometriosis who formed the |st group. 38 women with internal genital endometriosis were included into the $I^{\text {nd }}$ group. Control group involved 30 women without genital endometriosis. Doppler study was set in both phases of menstrual cycle with determination of uterine and intraovarian pulsatility index, resistance index and systolic/diastolic ratio in uterine arteries.

Results. In patients with endometriosis we found hemodynamic disturbances in uterine arteries of varying degrees which depended on localization of the pathological process and its stages. In women of I group with I and II stages of external endometriosis indices of peripheral vascular resistance did not differ significantly from parameters of the control group. There was moderate increase of vascular resistance indices higher over healthy women $(P<0.05)$ in this group in patients with III stage. Increase of peripheral vascular resistance was detected, which grew rapidly according to severity of disease by II-III stages of internal endometriosis. Critical changes of circulation in form of dicrotic notch were detected in $31.58 \%$ of patients with III stage of internal endometriosis. In half of all cases dicrotic notches were symmetrical in both uterine arteries. In addition, in $36.84 \%$ of patients with III degree of internal endometriosis negative blood flow in diastole phase was determined.

Significant important difference of pulsatility index and resistance index in intraovarian velocity between healthy women and patients with internal and external endometriosis was not determined, except persons with endometriod cysts, who had resistant index of intraovarian circulation in both phases of the menstrual cycle over 0.55 .

Conclusions. Blood velocity in uterine arteries during menstrual cycle in patients with genital endometriosis demonstrated highly resistant blood flow in women with external (III stage) and internal (II-III stages) endometriosis and intraovarian velocity (in persons with endometriod cysts). Decompensated changes in blood velocity in uterine arteries were observed only in patients with III stage of internal endometriosis.

\section{Аоплерометричне оцінювання кровоплину артерій матки та яєчників у хворих на генітальний ендометріоз}

\section{В. А. Воробій}

Поширення ендометріозу серед жінок репродуктивного віку становить 5-10\%. Формування ендометріоїдних вогнищ найчастіше починається з утворення нових кровоносних судин. Отже, зміни гемодинаміки в судинах, що можуть визначатися за допомогою доплерометрії, $є$ важливими для повної діагностики ендометріозу.

Мета роботи - оцінити маткові та інтраоваріальні гемодинамічні зміни в жінок із внутрішнім і зовнішнім генітальним ендометріозом.

Матеріали та методи. Обстежили 65 жінок із діагнозом зовнішнього генітального ендометріозу, які утворили I групу. 38 жінок із внутрішнім генітальним ендометріозом становили II групу. До контрольної групи ввійшли 30 жінок без діагнозу генітальний ендометріоз. Доплерометричне дослідження здійснили в обох фразах менструального циклу з визначенням пульсаційного індексу та індексу резистентності в маткових артеріях та інтраоваріально, а також систолодіастолічного співвідношення в маткових артеріях.

Результати. У пацієнток з ендометріозом виявили гемодинамічні порушення в маткових артеріях різного ступеня, які залежали від локалізації патологічного процесу та його стадій. У жінок I групи з I та II стадіями зовнішнього ендометріозу показники периферичного судинного опору не відрізнялися суттєво від значень контрольної групи. У цій групі в осіб із III стадією спостерігалось помірне підвищення показників судинного опору щодо здорових жінок $(p<0,05)$. При II-III стадіях внутрішнього ендометріозу виявлено збільшення периферичного судинного опору, яке підвищувалось залежно від тяжкості захворювання. Критичні зміни кровоплину у вигляді дикротичної виїмки констатовані у 31,58 \% пацієнток із III стадією внутрішнього ендометріозу. У половині всіх випадків дикротичні виїмки були симетричні в обох маткових артеріях. Крім того, у 36,84 \% пацієнток із III стадією внутрішнього ендометріозу визначався негативний кровоплин у діастолічній фразі. Не виявили суттєвої різниці показників пульсаційного індексу та індексу резистентності інтраоваріального кровоплину між здоровими жінками та пацієнтками з внутрішнім і зовнішнім ендометріозом, за винятком осіб з ендометріоїдною кистою, в яких індекс резистентності в обох фазах менструального циклу перевищував 0,55.

Висновки. Кровоплин у маткових артеріях упродовж менструального циклу в пацієнток із генітальним ендометріозом демонструє високу резистентність як при зовнішньому (III стадія), так і внутрішньому (II-III стадій) ендометріозі, а також інтраоваріально - за наявності ендометріоїдних кіст. Декомпенсовані зміни швидкості кровоплину в маткових артеріях спостерігаються тільки у випадках III стадії внутрішнього ендометріозу.
Key words: endometriosis, blood velocity, ultrasonics.

\section{Zaporozhye} medical journal 2017; 19 (4), 457-461 DOI: 10.14739/2310-1210 2017.4.105039

E-mail: v.vorobiy@ukr.net
Ключові слова: генітальний енАОМетріоз, кровотоку швиАкість, ультразвук.

Запорізький медичний журнал. - 2017. T. 19, № 4(103). C. 457-461 
Ключевые слова: генитальный энАОметриоз, кровотока скорость, ультразвук.

Запорожский медицинский журнал. - 2017. T. 19, № 4(103). C. 457-461

\title{
Аопплерометрическая оценка кровотока артерий матки и яичников у больных генитальным эндометриозом
}

\author{
В. А. Воробий
}

Распространение эндометриоза среди женщин репродуктивного возраста составляет 5-10\%. Формирование эндометриоидных очагов обычно начинается с образования новых кровеносных сосудов. Таким образом, изменения гемодинамики в сосудах, которые могут быть определены с помощью допплерометрии, важны для полной диагностики эндометриоза.

Цель работы - оценить маточные и интраовариальные гемодинамические изменения у женщин с внутренним и наружным генитальным эндометриозом.

Материалы и методы. Обследовано 65 женщин с диагнозом наружного генитального эндометриоза, которые образовали I группу. 38 женщин с внутренним генитальным эндометриозом составили II группу. В контрольную группу вошли 30 женщин без диагноза генитального эндометриоза. Допплерометрическое исследование было проведено в обеих фазах менструального цикла с определением пульсационного индекса и индекса резистентности в маточных артериях и интраовариально, а также систолодиастолического соотношения в маточных артериях.

Результаты. У пациенток с эндометриозом выявлены гемодинамические нарушения в маточных артериях различной степени, которые зависели от локализации патологического процесса и его стадий. У женщин I группы с I и II стадиями наружного эндометриоза показатели периферического сосудистого сопротивления не отличались существенно от показателей контрольной группы. В этой группе у лиц с III стадией наблюдалось умеренное повышение показателей сосудистого сопротивления относительно здоровых женщин $(p<0,05)$. При II-III стадиях внутреннего эндометриоза обнаружено увеличение периферического сосудистого сопротивления, которое повышалось в зависимости от тяжести заболевания. Критические изменения кровотока в виде дикротической выемки констатированы у 31,58\% пациенток c III стадией внутреннего эндометриоза. В половине всех случаев дикротические выемки были симметричны в обеих маточных артериях. Кроме того, у 36,84 \% пациенток с III стадией внутреннего эндометриоза определялся отрицательный кровоток в диастолической фазе. Мы не обнаружили существенного различия показателей пульсационного индекса и индекса резистентности интраовариального кровотока между здоровыми женщинами и пациентками с внутренним и наружным эндометриозом, за исключением лиц с эндометриоидной кистой, у которых индекс резистентности в обеих фазах менструального цикла превышал 0,55.

Выводы. Кровоток в маточных артериях на протяжении менструального цикла у пациенток с генитальным эндометриозом демонстрирует высокую резистентность как при наружном (III стадия), так и внутреннем (II-III стадии) эндометриозе, а также при наличии эндометриоидных кист - интраовариально. Декомпенсированные изменения скорости кровотока в маточных артериях наблюдаются только в случаях III стадии внутреннего эндометриоза.

In recent years the problem of endometriosis began to occupy the first places in gynecological practice. The spread of the disease among women of reproductive age is $5-10 \%$ [1], but some scientists indicate about more prevalence of endometriosis among females of reproductive age - up to $45 \%$ [2]. In addition, about $50 \%$ of women with infertility have this pathology [3]. Increase of frequency of endometriosis is most likely associated with more advanced diagnostic capabilities. However, lifestyle habits, metabolic changes, deterioration of ecological situation, genetic background factors and other aspects are important in the development of the disease [4]. Pain syndrome, menstrual disorders in the form of hemorrhagic syndrome, infertility are dominating clinical manifestations of endometriosis. This pathology significantly affects the quality of life of patients, leading to impairment of relations in the family and with other people, reducing professional and daily activities [5].

Clinical management of patients with endometriosis is still a debate process. Various groups of medications from symptomatic treatment till hormonal drugs, agonists of gonadotropin-releasing hormones, gonadotropin medications, aromatase inhibitors and so on are proposed for treatment. However, surgical operations of endometriosis in recent years are very successful. Therefore, it should be mentioned, that complete examination of patient with endometriosis is basic for choosing effective kind of treatment. In practical medicine Doppler assessment of blood flow in vessels of pelvic organs by endometriosis is not widely spread. Mostly attention is paid to changes of sizes and structure of internal genital organs by ultrasound echography. But it ought to re- member that forming of endometrioid foci commonly begins from development of new blood vessels [6]. So, changes of hemodynamics in vessels that can be determined by Doppler are important for complete diagnosis of endometriosis.

\section{Aim of research}

To evaluate the uterine and intraovarian hemodynamic changes in women with internal and external endometriosis.

\section{Materials and methods}

The research included 65 women with diagnosis of external genital endometriosis who formed the ${ }^{\text {st }}$ group. 38 women with internal genital endometriosis were included into the IInd group. This group also included patients with adenomyosis in combination with small myoma nodes (diameter less than $1.5-2.0 \mathrm{~cm}$ ). Control group involved 30 women of reproductive age without diagnosis of genital endometriosis and other hormonal or acute gynecological and extragenital pathologies. Verification of diagnosis was performed in accordance with Order \# 319 of Ministry of Health of Ukraine [1]. Diagnosis was based on the combination of clinical manifestations and specific methods of examinations (ultrasound, laparoscopy, hysteroscopy, morphology). Stages of external genital endometriosis were performed according to American Fertility Society classification, based on calculation of the total area and depth of endometrioid heterotopy, expressed in points (I - minimal endometriosis, 1-5 points; II - mild endometriosis, 6-15 points; III - moderate endometriosis, 
16-40 points; IV - severe endometriosis, more than 40 points). Internal endometriosis was also classified according to stages: I - pathological process is limited by submucous membrane of uterine body; II - pathological process involves myometrium; III - pathological process is located in whole myometrium till serous membrane of uterus; IV - involvement in pathological process, except uterus, parietal peritoneum of pelvis and nearby organs [7].

Ultrasound and Doppler examinations of pelvic organs were set in both phases of menstrual cycle (on 6-8 $8^{\text {th }}$ and 22-24 ${ }^{\text {th }}$ days) using 3.5, 7.5 and $9 \mathrm{MHz}$ transabdominal and transvaginal transducers (ultrasound machine PHILLIPS HD7). We determined uterine and intraovarian pulsatility index (PI), resistance index (RI) and systolic/diastolic ratio $(S / D$ ratio) in uterine arteries.

For statistical analysis we used program Statistica 6.0. We calculated arithmetic mean value, standard error of the mean, criterion $X^{2}$ (Yates corrected Chi-square), probability of differences results of research (p). To compare two independent groups on one feature we used nonparametric Mann-Whitney test, to compare two dependent groups Wilcoxon test. The difference between the values comparing considered reliable at $p<0.05$.

\section{Results}

The average age of women in the $\mathrm{Ist}^{\text {st }}$ and $\mathrm{II}^{\text {nd }}$ groups was statistically different $-27.88 \pm 0.48$ and $35.21 \pm 0.62$ years respectively $(P<0.05)$. Average age in control group was $28.57 \pm 0.76$ years. Patients of early and active reproductive age were predominated in I group. So, 15 women $(23.08 \%)$ were 20-24 years old, $33(50.77 \%)-25-29$ years, 17 (26.15\%) - 30-35 years. In contrast, among patients of II group persons of late reproductive age (36-40 years) constituted the majority ( 25 persons $-65.79 \%$ ), 4 women $(10.53 \%)$ were $25-29$ years old, $9(23.68 \%)-30-35$ years. Duration of diseases depended on location of pathology. 23 patients (35.39\%) with external endometriosis suffered from endometriosis for $1-3$ years, $30(46.15 \%)-4-6$ years, 12 $(18.46 \%)-7-10$ years. Such indices among women with internal endometriosis were 4 (10.53\%), 6 (15.79\%) and 28 (73.68\%) persons respectively.

Using clinical and instrumental examinations external genital endometriosis of the I and II stages were diagnosed in 25 women $(38.46 \%)$, the III stage - in $15(23.08 \%)$. Among patients in the IInd group $9(23.68 \%)$ women had I stage of disease, $10(26.32 \%)$ - II and $19(50.00 \%)$ - III.

The leading complaints in patients with external and internal endometriosis were algomenorrhea $(69.23 \%$ and $86.84 \%$ respectively) and dyspaureniya ( $43.08 \%$ and $42.11 \%$ ), which was determined by the severity of pain index (Table 1). Obviously, level of pain index in patients with external endometriosis did not indicate the extent of the disease, whereas in patients with internal endometriosis it reflected severity of the disease and was most pronounced in diffuse myometrium injury. Women from the IInd group suffered from pain which was not connected with menstrual cycle more often, than in the Ist group $\left(X^{2}=4.73, P<0.05\right)$.

Disorders of menstrual cycle like spot dark blood discharges before or after menses, hyperpolymenorrhae were more frequent in women with internal endometriosis $\left(X^{2}=7.64, P<0.01\right)$ comparers to external one. $10.8 \%$ per- sons with external endometriosis had no complaints against none patients with internal endometriosis $\left(X^{2}=4.84, P<0.05\right)$.

In both groups among general complaints the most spread were unmotivated weakness $(78.5 \%$ in I group and $92.0 \%$ - in II), malaise ( $64.5 \%$ and $84.0 \%$ respectively), increased fatigue (48.0\% and $64.0 \%)$. Most patients suffered from irritability, emotional liability, sleep disturbances, increased anxiety. It was established that common symptoms are often in various combinations and met with equal frequency in all stages of genital endometriosis.

Infertility was diagnosed in $24(36.92 \%)$ women with external endometriosis and $16(42.11 \%)$ - with internal one. In I group quantity of patients with primary infertility $(83.33 \%)$ was more than with secondary one $(16.67 \%)$. And in the contrary, in II group secondary infertility $(75.00 \%$, $X^{2}=11.29, P<0.001$ compared to I group) was more often than primary $\left(25.00 \%, X^{2}=11.29, P<0.001\right.$ compared to I group). Differences between spreading of type of infertility according to stage of disease were not found.

Results of Doppler examination of uterine and ovarian arteries demonstrated that in healthy women there were decrease of indexes of vessels resistance during menstrual cycle by reducing of peak systolic flow and the simultaneous increase of maximum final velocity diastolic flow (Table 2). There was no significant difference in blood circulation between right and left uterine arteries in different phases of cycle. This pattern of blood flow is ensured by adequate hormonal ovarian function. Estrogens have vasodilatation effect and progesterone has the opposite one.

In patients with endometriosis we found hemodynamic disturbances in uterine arteries of varying degrees which were depended on localization of the pathological process and its stages. In women of I group with I and II stages of external endometriosis indices of peripheral vascular resistance were not differ significantly by from parameters of control group. In persons with III stage there was moderate increase of vascular resistance indices higher over healthy women $(P<0.05)$. Thus, in patients with III stage of external endometriosis, despite the absence of objective instrumental data for internal endometriosis, there are predisposing factors for its development - increased indices of peripheral vascular resistance in the uterine arteries.

By all stages of internal endometriosis we found increase of peripheral vascular resistance, which grew rapidly according to severity of pathological process (Table 3). Thus, in patients of I stage these indexes were similar to controls,

Table 1. Clinical manifestations of patients with endometriosis

\begin{tabular}{|c|c|c|c|c|c|c|c|c|}
\hline \multirow[t]{2}{*}{ Symptoms } & \multicolumn{4}{|c|}{ I group (external endometriosis) } & \multicolumn{4}{|c|}{ II group (internal endometriosis) } \\
\hline & $\begin{array}{l}\mathrm{I}=25 \\
\mathrm{n}=25\end{array}$ & $\begin{array}{l}\text { II } \\
n=25\end{array}$ & $\begin{array}{l}\text { III } \\
n=15\end{array}$ & $\begin{array}{l}\text { Total } \\
n=65\end{array}$ & $\begin{array}{l}I \\
n=9\end{array}$ & $\begin{array}{l}\| I \\
n=10\end{array}$ & $\begin{array}{l}\text { III } \\
n=19\end{array}$ & $\begin{array}{l}\text { Total } \\
n=38\end{array}$ \\
\hline $\begin{array}{l}\text { Algodys- } \\
\text { menorrhea }\end{array}$ & $\begin{array}{l}20 \\
80.0 \%\end{array}$ & $\begin{array}{l}17 \\
68.0 \%\end{array}$ & $\begin{array}{l}8 \\
53.3 \%\end{array}$ & $\begin{array}{l}45 \\
69.2 \%\end{array}$ & $\begin{array}{l}5 \\
55.6 \%\end{array}$ & $\begin{array}{l}9 \\
90.0 \%\end{array}$ & $\begin{array}{l}19 \\
100.0 \%\end{array}$ & $\begin{array}{l}33 \\
86.8 \%\end{array}$ \\
\hline Dyspareunia & $\begin{array}{l}12 \\
48.0 \%\end{array}$ & $\begin{array}{l}10 \\
40.0 \%\end{array}$ & $\begin{array}{l}6 \\
40.0 \%\end{array}$ & $\begin{array}{l}28 \\
43.1 \%\end{array}$ & $\begin{array}{l}1 \\
11.1 \%\end{array}$ & $\begin{array}{l}3 \\
30.0 \%\end{array}$ & $\begin{array}{l}12 \\
63.2 \%\end{array}$ & $\begin{array}{l}16 \\
42.1 \%\end{array}$ \\
\hline Dyschezia & $\begin{array}{l}3 \\
12.0 \%\end{array}$ & $\begin{array}{l}2 \\
8.0 \%\end{array}$ & $\begin{array}{l}2 \\
13.3 \%\end{array}$ & $\begin{array}{l}7 \\
10.1 \%\end{array}$ & - & $\begin{array}{l}2 \\
20.0 \%\end{array}$ & $\begin{array}{l}4 \\
21.1 \%\end{array}$ & $\begin{array}{l}6 \\
15.8 \%\end{array}$ \\
\hline $\begin{array}{l}\text { Pain } \\
\text { not connected } \\
\text { with menses }\end{array}$ & $\begin{array}{l}7 \\
28.0 \%\end{array}$ & $\begin{array}{l}9 \\
86.0 \%\end{array}$ & $\begin{array}{l}6 \\
40.0 \%\end{array}$ & $\begin{array}{l}22 \\
33.9 \%\end{array}$ & $\begin{array}{l}3 \\
33.3 \%\end{array}$ & $\begin{array}{l}6 \\
60.0 \%\end{array}$ & $\begin{array}{l}13 \\
68.4 \%\end{array}$ & $\begin{array}{l}22 \\
57.9 \%\end{array}$ \\
\hline $\begin{array}{l}\text { Disorders of } \\
\text { menstrual cycle }\end{array}$ & $\begin{array}{l}3 \\
12.0 \%\end{array}$ & $\begin{array}{l}15 \\
20.0 \%\end{array}$ & $\begin{array}{l}14 \\
93.3 \%\end{array}$ & $\begin{array}{l}32 \\
49.2 \%\end{array}$ & $\begin{array}{l}5 \\
55.6 \%\end{array}$ & $\begin{array}{l}6 \\
60.0 \%\end{array}$ & $\begin{array}{l}19 \\
100.0 \%\end{array}$ & $\begin{array}{l}30 \\
78.9 \%\end{array}$ \\
\hline $\begin{array}{l}\text { Asymptomatic } \\
\text { course }\end{array}$ & $\begin{array}{l}3 \\
12.0 \%\end{array}$ & $\begin{array}{l}3 \\
12.0 \%\end{array}$ & $\begin{array}{l}1 \\
6.7 \%\end{array}$ & $\begin{array}{l}10 \\
10.8 \%\end{array}$ & - & - & - & - \\
\hline
\end{tabular}


Table 2. Uterine artery indices in patients with external endometriosis in both phases of menstrual cycle

\begin{tabular}{|c|c|c|c|c|c|c|c|c|}
\hline \multirow[t]{2}{*}{ Doppler indices } & \multicolumn{2}{|c|}{ Control group } & \multicolumn{3}{|l|}{ I phase } & \multicolumn{3}{|l|}{ II phase } \\
\hline & $\begin{array}{l}\text { I phase } \\
(n=30)\end{array}$ & $\begin{array}{l}\text { II phase } \\
(n=30)\end{array}$ & $\begin{array}{l}\text { I stage } \\
(n=25)\end{array}$ & $\begin{array}{l}\text { II stage } \\
(n=25)\end{array}$ & $\begin{array}{l}\text { III stage } \\
(n=15)\end{array}$ & $\begin{array}{l}\text { I stage } \\
(n=25)\end{array}$ & $\begin{array}{l}\text { II stage } \\
(n=25)\end{array}$ & $\begin{array}{l}\text { III stage } \\
(n=15)\end{array}$ \\
\hline \multicolumn{9}{|c|}{ Right uterine artery: } \\
\hline$S / D$ ratio & $3.55 \pm 0.15$ & $3.44 \pm 0.15$ & $3.57 \pm 0.16$ & $3.57 \pm 0.12$ & $3.94 \pm 0.16^{*}$ & $3.41 \pm 0.18$ & $3.65 \pm 0.17$ & $4.09 \pm 0.22^{*}$ \\
\hline IR & $0.65 \pm 0.01$ & $0.62 \pm 0.01$ & $0.64 \pm 0.01$ & $0.66 \pm 0.01$ & $0.72 \pm 0.01^{*}$ & $0.65 \pm 0.01$ & $0.66 \pm 0.01$ & $0.70 \pm 0.02^{*}$ \\
\hline $\mathrm{PI}$ & $1.45 \pm 0.06$ & $1.39 \pm 0.07$ & $1.49 \pm 0.09$ & $1.53 \pm 0.08$ & $1.83 \pm 0.16^{*}$ & $1.47 \pm 0.11$ & $1.56 \pm 0.09$ & $1.93 \pm 0.10^{*}$ \\
\hline$S / D$ ratio & $3.47 \pm 0.13$ & $3.32 \pm 0.15$ & $3.48 \pm 0.14$ & $3.61 \pm 0.18$ & $3.85 \pm 0.14^{*}$ & $3.47 \pm 0.19$ & $3.58 \pm 0.19$ & $3.98 \pm 0.24 *$ \\
\hline IR & $0.63 \pm 0.01$ & $0.61 \pm 0.01$ & $0.64 \pm 0.01$ & $0.65 \pm 0.01$ & $0.70 \pm 0.01^{*}$ & $0.64 \pm 0.01$ & $0.63 \pm 0.01$ & $0.68 \pm 0.01^{*}$ \\
\hline PI & $1.40 \pm 0.06$ & $1.32 \pm 0.07$ & $1.44 \pm 0.08$ & $1.49 \pm 0.08$ & $1.77 \pm 0.09^{*}$ & $1.47 \pm 0.09$ & $1.52 \pm 0.11$ & $1.90 \pm 0.13^{*}$ \\
\hline
\end{tabular}

*: probability of the difference of indicator relative to control group $(P<0.05)$.

Table 3. Uterine artery indices in patients with internal endometriosis in both phases of menstrual cycle

\begin{tabular}{|c|c|c|c|c|c|c|c|c|}
\hline \multirow[t]{2}{*}{ Doppler indices } & \multicolumn{2}{|c|}{ Control group } & \multicolumn{3}{|l|}{ I phase } & \multicolumn{3}{|l|}{ II phase } \\
\hline & $\begin{array}{l}\text { I phase } \\
(n=30)\end{array}$ & $\begin{array}{l}\text { II phase } \\
(n=30)\end{array}$ & $\begin{array}{l}\text { I stage } \\
(n=9)\end{array}$ & $\begin{array}{l}\text { II stage } \\
(n=10)\end{array}$ & $\begin{array}{l}\text { III stage } \\
(n=19)\end{array}$ & $\begin{array}{l}\text { I stage } \\
(n=9)\end{array}$ & $\begin{array}{l}\text { II stage } \\
(n=10)\end{array}$ & $\begin{array}{l}\text { III stage } \\
(n=19)\end{array}$ \\
\hline \multicolumn{9}{|c|}{ Right uterine artery: } \\
\hline$S / D$ ratio & $3.55 \pm 0.15$ & $3.44 \pm 0.15$ & $3.73 \pm 0.28$ & $4.51 \pm 0.38^{*}$ & $6.01 \pm 0.33^{*}$ & $3.64 \pm 0.22$ & $4.31 \pm 0.36^{*}$ & $5.40 \pm 0.21^{*}$ \\
\hline IR & $0.65 \pm 0.01$ & $0.62 \pm 0.01$ & $0.67 \pm 0.01$ & $0.74 \pm 0.02^{*}$ & $0.81 \pm 0.01^{*}$ & $0.69 \pm 0.01$ & $0.75 \pm 0.03^{*}$ & $0.79 \pm 0.02^{*}$ \\
\hline $\mathrm{PI}$ & $1.45 \pm 0.06$ & $1.39 \pm 0.07$ & $1.67 \pm 0.12$ & $1.87 \pm 0.19^{*}$ & $2.15 \pm 0.11^{*}$ & $1.60 \pm 0.14$ & $1.86 \pm 0.13^{*}$ & $2.09 \pm 0.12^{*}$ \\
\hline \multicolumn{9}{|l|}{ Left uterine artery: } \\
\hline$S / D$ ratio & $3.47 \pm 0.13$ & $3.32 \pm 0.15$ & $3.69 \pm 0.31$ & $4.37 \pm 0.28^{*}$ & $5.88 \pm 0.33^{*}$ & $3.52 \pm 0.23$ & $4.23 \pm 0.26^{*}$ & $5.33 \pm 0.25^{*}$ \\
\hline IR & $0.63 \pm 0.01$ & $0.61 \pm 0.01$ & $0.66 \pm 0.02$ & $0.74 \pm 0.02^{*}$ & $0.79 \pm 0.01^{*}$ & $0.68 \pm 0.02$ & $0.74 \pm 0.02^{*}$ & $0.78 \pm 0.02^{*}$ \\
\hline $\mathrm{PI}$ & $1.40 \pm 0.06$ & $1.32 \pm 0.07$ & $1.55 \pm 0.17$ & $1.84 \pm 0.15^{*}$ & $2.02 \pm 0.13^{*}$ & $1.54 \pm 0.13$ & $1.81 \pm 0.15^{\star}$ & $1.99 \pm 0.11^{*}$ \\
\hline
\end{tabular}

": probability of the difference of indicator relative to control group $(P<0.05)$.

II-III stages - difference was significant higher over healthy women. Similar changes were determined in both uterine arteries. Critical changes in blood flow can be manifested in the form of dicrotic notch between diastolic peak systolic velocity and maximum one that reaches baseline.

Critical changes of circulation were detected in 6 $(31.58 \%)$ of patients with III stage of the disease. In half of all cases dicrotic notches were symmetrical in both uterine arteries. In addition, in 7 (36.84\%) of patients with III degree of internal endometriosis negative blood flow in diastole phase was determined. It can mean significant changes in blood supply of uterus. In the second phase of the menstrual cycle, in contrast to the control group, there is no gradual decrease in peripheral vascular resistance indices in persons with internal endometriosis. In patients with II and III stages these parameters remained high and differ significantly from physiological ones.

It is worth to mention that all patients with critical changes of blood velocity had such parameters with negative values in diastole phase of menstruation in both phases of menstrual cycle. This can be criterion of decompensation of arterial blood flow in uterus. Such patients had complains on hemorrhagic syndrome and severe pain syndrome that was not stopped from receiving non-narcotic analgesics.

We did not determine significant important difference of RI and PI between healthy women and patients with internal and external endometriosis. However, in control group in follicle phase of menstrual cycle RI was $0.51 \pm 0.01$, PI $0.70 \pm 0.03$, in luteal phase $-0.43 \pm 0.02$ and $0.59 \pm 0.02$ respectively. Obviously, at $6-8$ th days of menses there were increased levels $\mathrm{RI}$ and $\mathrm{PI}$, but mostly in women with external endometriosis (I group $-0.54 \pm 0.03$ and $0.80 \pm 0.03$, II group $-0.52 \pm 0.02$ and $0.78 \pm 0.02$ ). In the second phase of menstrual cycle we found increase of these indices in patients from the Ist $(0.50 \pm 0.03$ and $0.65 \pm 0.04)$ and the IInd groups $(0.46 \pm 0.03$ and $0.63 \pm 0.02$ respectively). In patients with external endometriosis indices of peripheral vascular resistance of intraovarian velocity were fairly higher than those in patients with internal. Women with endometriod cysts had RI in intraovarian circulation in both phases of the menstrual cycle over $0.55(\mathrm{P}<0.05)$.

Thus, the obtained results prompt to evaluate importance of complete Doppler examination of uterine and ovarian arteries for differentiated treatment of patient with genital endometriosis and indications for surgical management. The presence of decompensation of blood circulation in uterine arteries in both phases of menstrual cycle may be the basis for deciding about possibility of surgical treatment of this pathology.

\section{Conclusions}

1. Doppler studies of uterine blood velocity during menstrual cycle in patients with genital endometriosis demonstrated equally direction of hemodynamic disorders in patients with external (III stage) and internal (II-III stages) endometriosis - highly resistant blood flow compared to healthy women $(P<0.05)$. Decompensated changes in blood velocity in uterine arteries were observed only in cases of the IIIrd stage of internal endometriosis.

2. Doppler indices of intraovarian blood velocity during menstrual cycle were increased in patients with endometriod cysts.

3. Presence of decompensation of blood circulation in uterus in both phases of menstrual cycle may be the basis for deciding on possibility of surgical treatment of this pathology. 


\section{References}

[1] (2016). Nakaz Ministerstva va okhorony zdorovia Ukrainy «Taktyka vedennia patsiientok $z$ henitalnym endometriozom» vid 06.04.2016r. №319 [Order of the Ministry of Health of Ukraine Management of patients with endometriosis from April, 4. 2016. №319]. Retrieved from http://moz. gov.ua/ua/portal/dn 20160406 0319.html. [In Ukrainian].

[2] Exacoustos, C., Manganaro, L., \& Zupi, E. (2014). Imaging for the evaluation of endometriosis and adenomyosis. Best Pract Res Clin Obstet Gynaecol, 28(5), 655-681. doi: 10.1016/j.bpobgyn.2014.04.010.

[3] Cranney, R., Condous, G., \& Reid, S. (2017). An update on the diagnosis, surgical management, and fertility outcomes for women with endometrioma. Acta Obstet Gynecol Scand, 96(6), 633-643. doi: 10.1111/aogs.13114

[4] Hart, R. J. (2016). Physiological Aspects of Female Fertility: Role of the Environment, Modern Lifestyle, and Genetics. Physiol Rev, 96(3), 873-909. doi: 10.1152/physrev.00023.2015.

[5] Lövkvist, L., Boström, P., Edlund, M., \& Olovsson, M. (2016). Age-Related Differences in Quality of Life in Swedis $\mathrm{h}$ Women with Endometriosis. J Womens Health (Larchmt), 25(6), 646-653. doi: 10.1089/jwh.2015.5403.

[6] El-Mazny, A., Kamel, A., Ramadan, W., Gad-Allah, S., Abdelaziz, S., \& Hussein, A. M. (2016). Effect of ovarian endometrioma on uterine and ovarian blood flow in infertile women. Int J Womens Health, 28(8) 677-682. doi: 10.2147/IJWH.S124229.

[7] Adamyan, L. V., Andreeva, E. N., Apolikhina, I. A., Bezhenar', V. F. Gevorkyan, M. A., \& Gus, A. I. (2013). E'ndometrioz: diagnostika, lechenie i reabilitaciya: federal'nye klinicheskie rekomendacii po vedeniyu bol'nykh [Endometriosis: diagnosis, treatment and rehabilitation. Federal clinical recommendations of patient's management]. Moscow. [In Russian].

\section{Information about author:}

Vorobii V. D., MD, PhD, Associate Professor, Department of Obstetrics and Gynecology, State Higher Educational Establishment "Ivano-Frankivsk National Medical University", Ukraine.

\section{Відомості про автора:}

Воробій В. А., А-р меА. наук, Аоцент каф. акушерства та гінекології, АВНЗ «Івано-Франківський національний меАичний університет", Україна.

\section{Сведения об авторе:}

Воробий В. А., А-р меА. наук, Аоцент каф. акушерства и гинекологии, гВУЗ “Ивано-Франковский национальный медицинский университет", Украина.

Конфмікт інтересів: віАсутній.

Conflicts of Interest: author has no conflict of interest to declare.

Надійшло Ао редакції / Received: 23.03.2017

Після Аоопрацювання / Revised: 27.03.2017

Прийнято Ао Аруку / Accepted: 28.03.2017 